University of Nebraska - Lincoln

DigitalCommons@University of Nebraska - Lincoln

\title{
Geomorphic-vegetation relationships using a geopedological classification system, northern Chihuahuan Desert, USA
}

\author{
G.A. Michaud \\ USDA Natural Resource Conservation Service \\ H.C. Monger \\ New Mexico State University, cmonger@nmsu.edu \\ D.L. Anderson \\ White Sands Missile Range
}

Follow this and additional works at: https://digitalcommons.unl.edu/usdaarsfacpub

Michaud, G.A.; Monger, H.C.; and Anderson, D.L., "Geomorphic-vegetation relationships using a geopedological classification system, northern Chihuahuan Desert, USA" (2013). Publications from USDAARS / UNL Faculty. 1167.

https://digitalcommons.unl.edu/usdaarsfacpub/1167

This Article is brought to you for free and open access by the U.S. Department of Agriculture: Agricultural Research Service, Lincoln, Nebraska at DigitalCommons@University of Nebraska - Lincoln. It has been accepted for inclusion in Publications from USDA-ARS / UNL Faculty by an authorized administrator of DigitalCommons@University of Nebraska - Lincoln. 


\title{
Geomorphic-vegetation relationships using a geopedological classification system, northern Chihuahuan Desert, USA
}

\author{
G.A. Michaud ${ }^{\mathrm{a}}$, H.C. Monger ${ }^{\mathrm{b}, *}$, D.L. Anderson ${ }^{\mathrm{c}}$ \\ ${ }^{a}$ USDA Natural Resource Conservation Service, Las Cruces, NM 88011, USA \\ ${ }^{\mathrm{b}}$ New Mexico State University, Las Cruces, NM 88003-8003, USA \\ ${ }^{\mathrm{c}}$ White Sands Missile Range, NM, USA
}

\section{A R T I C L E I N F O}

\section{Article history:}

Received 5 May 2011

Received in revised form

23 September 2012

Accepted 2 October 2012

Available online 1 December 2012

\section{Keywords:}

Arid-semiarid ecosystems

Desert ecology

Desert geomorphology

Desert soils

Desert vegetation

Gypsum soils

Jornada Experimental Range

White Sands

\begin{abstract}
A B S T R A C T
Drylands typically have distinctive vegetative patterns that reflect the underlying physical landscape. We use a geopedological classification to organize the landscape into five categories from broad scale to fine scale: (1) physiographic divisions which describe regional topography, such as mountains and basin floors; (2) regolith type which identifies residuum versus transported sediments; (3) parent materials which describe mineralogy; (4) landforms which provide meso-scale descriptions of topography; and (5) soil texture, a fine-scale variable important for infiltration, erodibility, and available water holding capacity. The study was conducted in a $1753 \mathrm{~km}^{2}$ area of the White Sands Missile Range and easternmost Jornada Experimental Range and revealed the following. (1) At the broadest scale, mesquite is dominant on the basin floor when the parent material is siliceous sand, but (2) biological soil crust becomes dominant in the basin floor when the parent material is gypseous. (3) Creosotebush is dominant on rocky soils of the piedmont slopes regardless of parent material, but (4) grasslands become dominant on the bajadas upslope in the semiarid zone and into the semiarid mountain uplands regardless of bedrock type. This method provides a way of supplementing ecologic-edaphic studies and provides a framework within which mechanisms can be explored.
\end{abstract}

(c) 2012 Elsevier Ltd. All rights reserved.

\section{Introduction}

Distinct patterns of vegetation exist in arid and semiarid landscapes. Distinct physical patterns of bedrock, landforms, and soils also exist in those same landscapes. Developing a better understanding of the relationship between vegetation and the physical landscape (i.e., geomorphology) is a continuing quest for many scientists and land managers working in dryland regions. Research focusing on vegetative-geomorphic relationships can generally be placed into four groups: studies of factors intrinsic to the plant community (i.e., soil as substrate), studies of factors extrinsic to the plant community (e.g., runoff versus run-in), studies focused on broad-scale relationships (i.e., landscape), and studies focused on fine-scale (i.e., hillslope) relationships.

Intrinsic factors consist of "on the spot" internal soil physical and chemical properties that affect plant growth (Zonneveld, 1989). Important physical intrinsic factors include clay content (Yao et al., 2006), infiltration (Breshears and Barnes, 1999; Hammerlynck et al.,

\footnotetext{
* Corresponding author. Tel.: +1 575646 1910; fax: +1 5056466041.

E-mail address: cmonger@nmsu.edu (H.C. Monger).
}

2002; Herrick et al., 2002), and available water holding capacity (Duniway et al., 2007). Important chemical intrinsic factors include salinity (Dregne, 1991) and nutrient reserves (Box, 1961; Schlesinger et al., 1996).

Extrinsic factors include the effects of topography that modify local temperature and precipitation as the result of elevation, slope steepness, and slope orientation that impact soil moisture and the lateral movement of nutrients through the landscape (Cammeraat, 2002; Parsons et al., 2003; Schlesinger et al., 2000; Wainwright et al., 2000; Wondzell et al., 1996). In this regard, landform descriptors, such as local curvature, landscape concavity, and convexity, have been useful for quantifying the landscape and providing insights about which mechanisms are responsible for how vegetation organizes into patterns (Yetemen et al., 2010). Other extrinsic factors include those imposed by humans, such as land management and livestock grazing (Peters et al., 2006).

Broad-scale relationships address biome- and ecotone-scale questions dealing with why certain plant communities are found on some landscapes but not others as the result of long-term water movement, erosion, and organic matter fluxes (McAuliffe, 1994; Satterwhite and Ehlen, 1982; Wondzell et al., 1987). Studies of finescale relationships include questions about how plant communities 
developed in relation to hillslope zones of water production, transfer, and sinks (Bestelmeyer et al., 2006a; Ludwig et al., 2005; Pickup, 1985; Wierenga et al., 1987). Because important information can be obtained at all scales, much insight is gained by scrutinizing vegetative-physical landscape relationships at multiple scales simultaneously (Bestelmeyer et al., 2006b; Monger and Bestelmeyer, 2006; Peters et al., 2004; Puigdefabregas et al., 1999).

This study also advocates a multi-scale approach. In particular, we describe a method designed to incorporate a geological understanding of vegetative patterns that expands the traditional method of examining correlations between soil series and vegetation (e.g., Buffington and Herbel, 1965). This geopedological approach stratifies the physical landscape into five categories linked in a hierarchal manner from broad scale to fine scale: (1) physiographic divisions, (2) regolith types, (3) parent materials, (4) landforms, and (5) soil textures (Fig. 1). Relationships between vegetation and each geopedological category can be viewed individually or in multiple combination using GIS.

\section{Geopedological categories and their linkage to vegetation patterns}

(1) Physiographic divisions describe the general shape of the regional landscape (Peterson, 1981). This category consists of large topographic features, such as local mountains, river valleys, and basin floors that formed as a result of tectonic, volcanic, and erosional processes on a time scale of millions of years (Hawley, 2005). The purpose of the physiographic divisions category is to provide a broad-scale context of the landscape. It allows the investigator to view vegetation patterns as

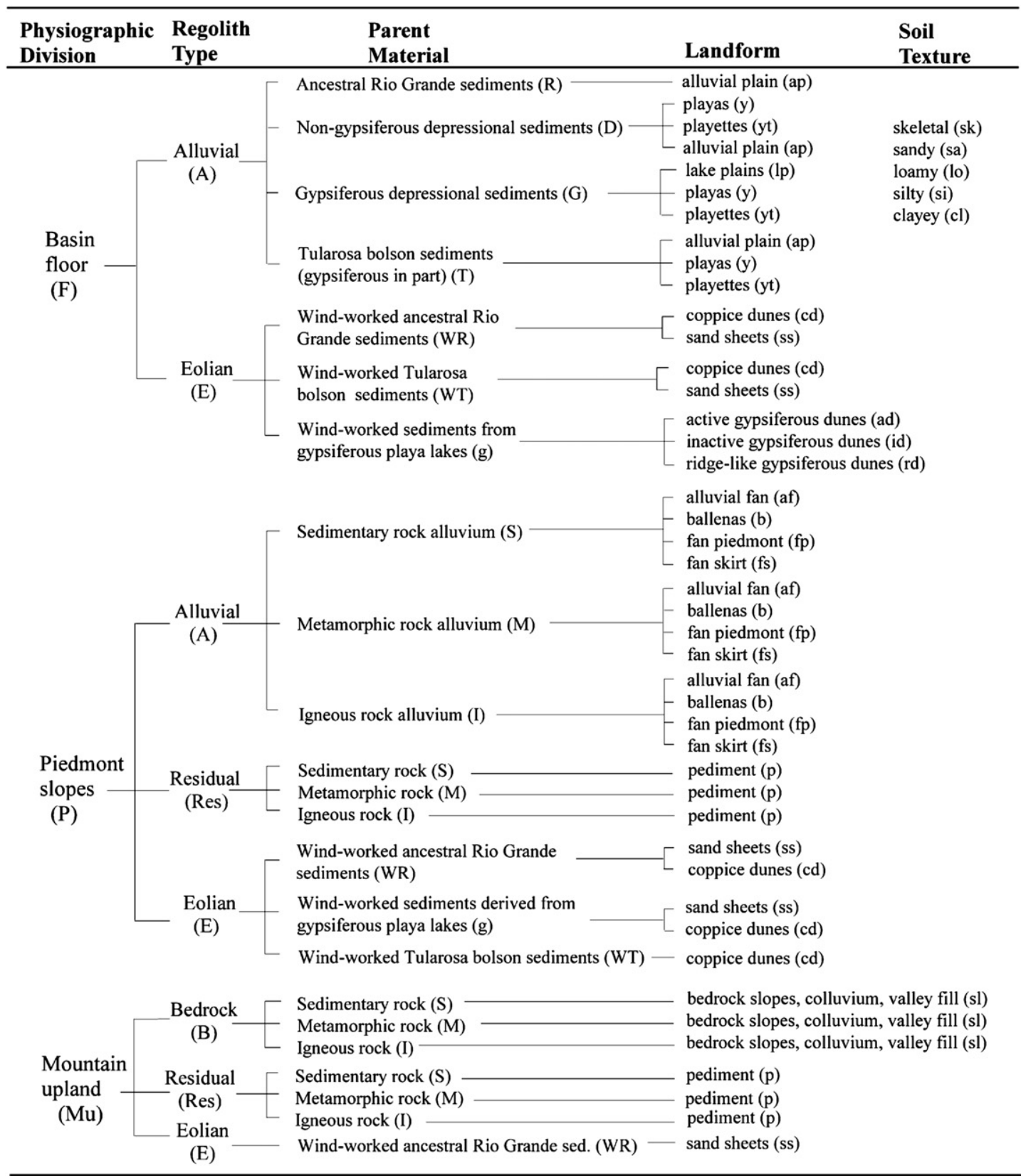

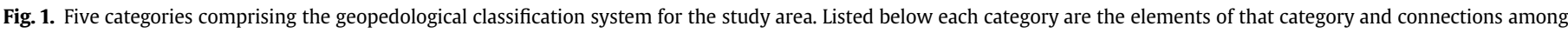
the elements. Abbreviations used on the geopedological maps are given in parenthesis. Soil texture elements may be applied to any landform. 
they are linked to local geology and climate differences controlled by elevation, aspect, and the lateral movement of water.

(2) Regolith type. Regolith is the unconsolidated material above bedrock. This category identifies where substrate formed in place (i.e., residuum) and where it occurs as sediment moved across the landscape by wind and water on time scales ranging from decades to millions of years (Gile et al., 1981; Weems and Monger, 2012). The purpose of this division is to provide an intermediate-scale category within which parent materials can be organized (Fig. 1). The main link between regolith types and vegetation pivots around soil texture. Eolian deposits in the study area, for example, are sandy and homogeneous, lacustrine deposits are silty to clayey and stratified, and alluvial fan deposits are gravelly and poorly sorted. When regolith occurs as episodic and punctuated sedimentary deposits they provide information about prehistoric landscape stability based on the premise that erosion and sedimentation are greater in shrublands, which have much bare ground, than in grasslands or woodlands (Abrahams et al., 1995; Gile and Hawley, 1966; Monger et al., 2009).

(3) Parent material as a geopedologic category makes it possible to differentiate lithic characteristics inherited by soil and their effect on chemical and physical properties. Chemical properties include supply of nutrients, namely calcium, phosphorus, magnesium, and potassium (Alexander et al., 1989), as well as salinity and sodicity (Dregne, 1976). Physical properties inherited from parent materials include erodibility, infiltration, water holding capacity, and shrink-swell properties (Coulombe et al., 2000; McFadden and McAuliffe, 1997).

(4) Landforms are recognizable forms at the Earth's surface having characteristic shapes, such as alluvial fans, playas, lake plains, and sand sheets (Bates and Jackson, 1987). In aggregate, landforms make up a landscape. They occur at a finer scale than physiographic parts and form on a time scale of decades to millions of years (Hawley, 2005). The purpose of including landforms as a geopedologic category is to provide meso-scale descriptions of landscape configuration that have important impacts on microclimate as the result of their control on overland flow (Rango et al., 2006) and slope aspect (DickPeddie, 1993). In addition, landforms differ in their erodibility. Moreover, vegetation change is more rapid on some landforms than others. Sandy basin floors and rocky piedmont slopes, for example, are more vulnerable to vegetative change than playas or desert mountains (Rachal et al., 2012).

(5) Soil texture, or particle size distribution, is a fundamental physical property. It controls many important variables that affect vegetation patterns, such as infiltration, available water holding capacity, and cation exchange capacity (Duniway et al., 2007; Hallmark and Allen, 1975). Soil texture is included as a geopedological category because of its long- and widelyrecognized influence on vegetation patterns (Browning et al., 2008; Gardner, 1951; Little and Campbell, 1943; Wondzell and Ludwig, 1995).

\section{Methods}

\subsection{Study area}

The south-central New Mexico study area consisted of 175,385 ha $(433,386$ acres $)$ in the southern White Sands Missile Range (WSMR) and eastern Jornada Experimental Range (Fig. 2). Climatically, this region is in the northern Chihuahuan Desert (Schmidt, 1979) and is dominated by desert scrub vegetation (about
$70 \%$ ) characterized by creosotebush, tarbush, and other shrubs and cacti that provide the basic community matrix, with minor amounts (about 5\%) of grasslands composed of black, blue, and sideoats grama, plus threeawns, tobosa, and other grasses (Beck and Gibbens, 1999). Physiographically, it is in the Basin and Range Province (Fenneman, 1931) and is dominated by block-faulted mountains composed of various combinations of igneous, metamorphic, and sedimentary rocks separated by structural basins (grabens) filled with Tertiary and Quaternary alluvium (Seager et al., 1987).

The study area straddles the north-south trending San AndresOrgan Mountains chain. The Jornada Basin is to the west and the Tularosa Basin is to the east. Both basins are part of the Rio Grande rift tectonic zone that started forming in the Oligocene (Seager et al., 1984). To the west of the San Andres-Organ Mountains, late Quaternary alluvium eroded from mountain uplands grades downslope to ancestral Rio Grande deposits of the Jornada Basin (Monger et al., 2006). On the east side of the San Andres-Organ Mountains, late Quaternary piedmont slope sediments grade to the Tularosa basin where, in the southern section, they merge with fluvial deposits of the ancestral Rio Grande (Seager et al., 1987). Farther north, piedmont slope deposits grade to gypsiferous basin fill deposits and Quaternary lake sediments (Allen et al., 2009; Hawley, 1993). A modern ephemeral lake, Lake Lucero, is located in the north-central part of the study area at the White Sands National Monument. Lake Lucero is the remnant of a former late-Pleistocene pluvial lake (Lake Otero) that has given rise to the largest gypsum dune field in the world (Langford, 2003).

\subsection{Geopedological and vegetative map units using GIS}

The geopedological units were mapped by ground-truthing delineations made on 1:24,000 stereo-pair aerial photography and 1991 Landsat-5 Thematic Mapper (TM) images using the near infrared composite TM band combination of 4-3-2. These bands were useful for revealing zones of vegetation, bare silty ground, and gypsum. Verification of the geopedological boundaries was done by performing ground-truthing transects across $85 \%$ of the map unit area. In addition, the study area is currently an active soil survey area by the USDA-NRCS which has provided further ground-truthing opportunities. Seven study trenches with soil characterization data (e.g., particle-size, available water capacity, mineralogy, electrical conductivity, etc.) are available at http:// soils.usda.gov for pedon numbers (S2006NM-688010, -688011, $-688012,-688013,-688014,-688015,-688016)$. Five additional sites in the study area (pedons 59-1, 60-19, 65-2, 65-3, and 65-4) are part of the Desert Soil-Geomorphology Project (Gile and Grossman, 1979). Another 15 unpublished soil profiles were described in the basin floor during May 2010 and two more NRCS profiles were described and sampled in May 2012. Particle-size distribution data used for soil texture elements shown in Fig. 1 were obtained from the White Sands Missile Range Soil Survey (Neher and Bailey, 1976). Those textural names correspond to the definitions for the family textural classes of Soil Taxonomy (Soil Survey Staff, 1999) with, for example, "skeletal" meaning a soil with greater than $35 \%$ coarse fragments ( $>2 \mathrm{~mm}$ ).

Map unit convention for the geopedologic categories combines elements listed in Fig. 1. In a geopedological map unit, the elements were separated by commas. If more than one element existed in a category they were distinguished in two ways: a virgule $(/)$ if one element overlaid another or a hyphen (-) if two elements occurred as discrete neighbors. In the hyphenated case, the dominant element was on the left with decreasing elements proceeding to the right. For example, the geopedological unit F, (E/A)-A, (WR/T)G, (cd/ap)-yt, (sa/lo)-cl shown in Fig. 2 has the following meaning. 


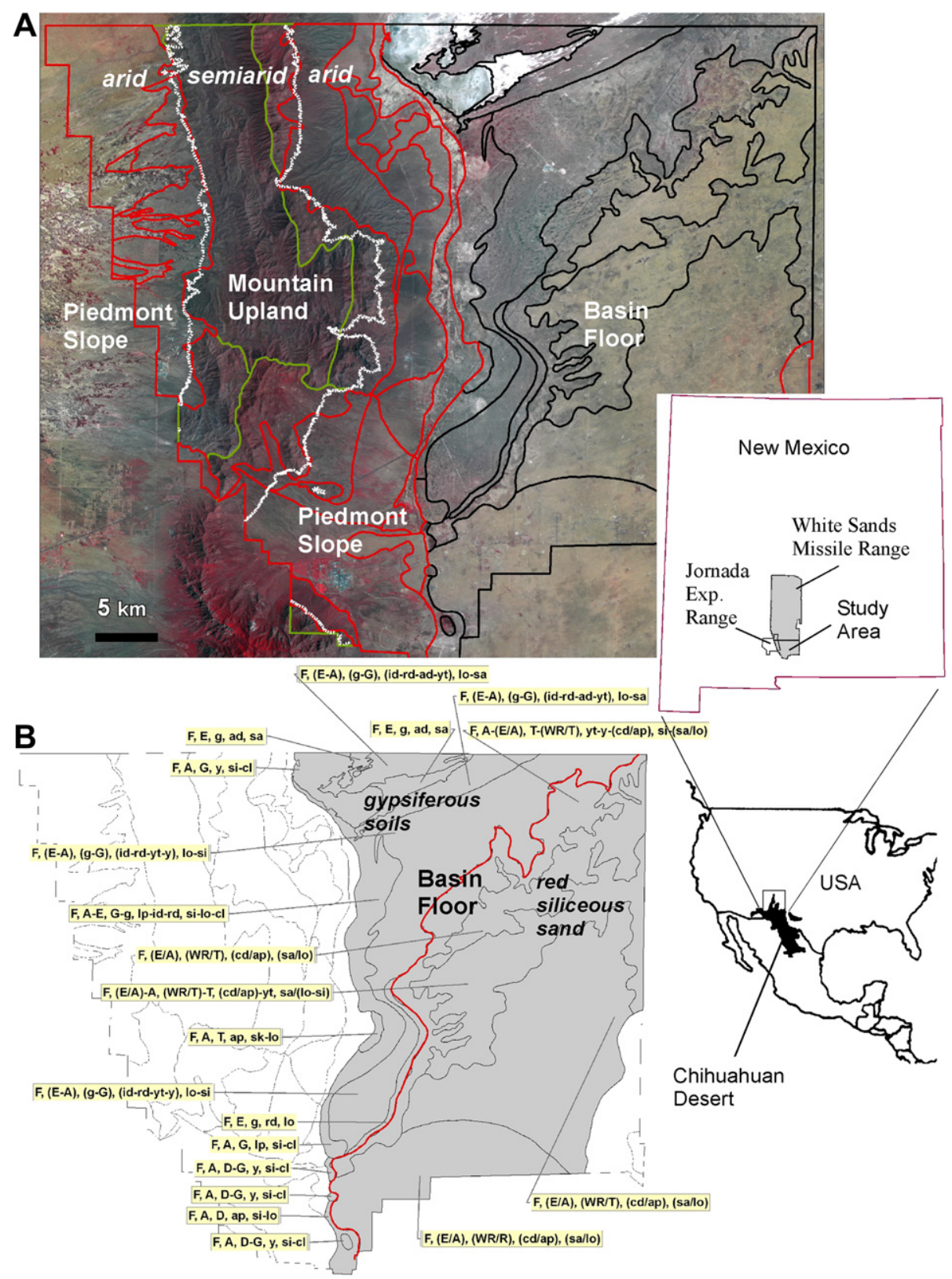

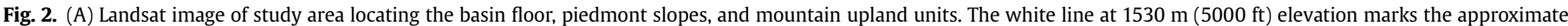

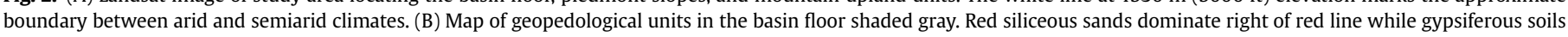
dominate left of the red line. (For interpretation of the references to color in this figure legend, the reader is referred to the web version of this article.)

The first category, physiographic part, is basin floor (F) (Fig. 1). The second category, regolith type, is the eolian element (E) overlying the alluvial element $(A)$ with lesser amounts of unburied alluvium (A). The third category, parent material, consists of wind-worked ancestral Rio Grande sediment (WR) overlying Tularosa basin sediments $(T)$ with lesser amounts of gypsiferous depressional sediments $(\mathrm{G})$. The fourth category, landforms, denotes the dominance of coppice dunes (cd) overlying an alluvial plain (ap) landform with lesser amounts of neighboring playettes (yt). The last category, soil texture, consists of sandy textures associated with the coppice dunes overlying loamy textures (lo) of the alluvial plain and clayey textures of the playettes (cl). Slope aspect, which can have a significant impact on vegetation, can be added to the landform element.

Vegetative map units used in this study are from "The Vegetation of White Sands Missile Range, New Mexico" (Muldavin et al., 2000a, 2000b). Their vegetation map was made by reading 1739 vegetation plots, approximately 1 per 1000 acres, from 1991 through 1995. The vegetation was classified using the United States National Vegetation Classification System (Grossman et al., 1998). It exists in Arc/Info Grid ${ }^{\mathrm{TM}}$ format, projected in NAD 83, UTM Coordinate System with a projected accuracy of $80 \%$, which can be applied to a 1:100,000 scale or smaller. The fundamental map unit is the vegetation alliance. Plant species comprising each vegetation alliance are listed in Appendix 1. Like many arid and semiarid regions, the vegetation patterns in this study area have been impacted by land use. Except for the unit "road disturbance," our study only focused on the relationships between current vegetation and natural landscape attributes.

Using GIS methodology, the geopedological map was overlain and compared to the 2000 White Sands Missile Range Vegetation Map using standard methods of data capture, storage, 
management, retrieval, analysis, and display (Walsh et al., 1998). The GIS process involved converting each of the digital elevation models (DEMs) into a grid with a $30-\mathrm{m}$ by $30-\mathrm{m}$ grid cell size, with each DEM projected into the North American Datum (NAD) 83 with Universal Transverse Mercator (UTM) coordinate system. This allowed the 17 individual DEM grids to be joined into a single DEM grid coverage, providing the elevation range for the study area. An aspect grid, and slope grid coverage was created from the single DEM grid coverage, with a $30-\mathrm{m}$ by 30 - $\mathrm{m}$ grid cell size for the entire study area. The grid coverages were put into a mathematical addition equation using the map calculator in ArcView Spatial Analyst $^{\circledR}$ (Michaud, 2000).

\section{Results}

\subsection{Total study area}

There are many hundreds of ways elements comprising the geopedological units can be combined to evaluate vegetativephysical landscape relationships. The combinations discussed in the following sections were the very apparent relationships observed during soil and landform mapping that occur at the broad-scale, meso-scale, and fine-scales. In the total study area there are 50 geopedological units. Nineteen are on the basin floor, 23 are on the piedmont slope, and 8 are on the mountain uplands (Fig. 2). The basin floor encompasses 90,140 ha (51.4\% of the study area); the piedmont slope, 54,668 ha (31.2\% of study area); and the mountain uplands, 30,576 ha (17.4\% of study area). For the basin floor, the dominant vegetation alliance is mesquite shrubland which occupies $51.3 \%$ (Fig. 3). For the piedmont slopes, the dominant vegetation alliance is creosotebush shrubland which occupies $29.4 \%$. For the mountain upland, the dominant vegetation alliance is grasslands which occupies $46.7 \%$.

\subsection{Basin floor}

The significant subdivisions of the basin floor are not topo-

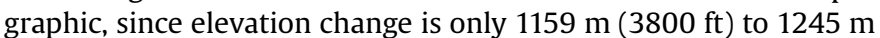
(4100 ft), but are instead the result of abrupt boundaries between gypsum and siliceous parent material, plus soil textures that range from sandy eolian deposits to clayey lacustrine deposits. Siliceous sand, which occupy slightly more than half the basin floor (Fig. 2B), originated from ancestral Rio Grande deposits (Hawley, 1975; Seager, 1981). The sand grains are coated with thin iron oxide that display a red color on aerial photography and satellite images. The basin floor unit contains 52 listed plant species in 13 vegetation alliances (Appendix 1). After mesquite shrubland (51.3\%), the dominant vegetative alliances are soil biological crust "cryptobiotic crust" (15.3\%), fourwing saltbush (7.2\%), and mixed lowland desert scrub (7.2\%) (Fig. 3).

Gypsum parent material and soil texture were scrutinized separately using the geopedological approach because of their historic importance for vegetation patterns (Campbell and Campbell, 1938; Herrero and Porta, 2000; Herrero et al., 2009). To evaluate these factors, the four most common vegetation alliances of the basin floor were examined with respect to (1) siliceous parent material combined with soil texture and (2) gypsiferous parent material combined with soil texture (Fig. 4). On siliceous sandy/loamy parent material, mesquite is the dominant vegetation alliance occupying $38 \%$ of the total 90,140 -ha basin floor area. On gypsiferous parent material, mesquite is uncommon. Instead, biological soil crust on loamy and silty soils is dominant (9.4\%), followed by fourwing saltbush on loamy and silty soils (4.4\%) (Fig. 4).

Upon groundtruthing these relationships, there is an obvious correspondence between mesquite coppice dunes and the red siliceous sands. Similarly, it was observed that the biological soil

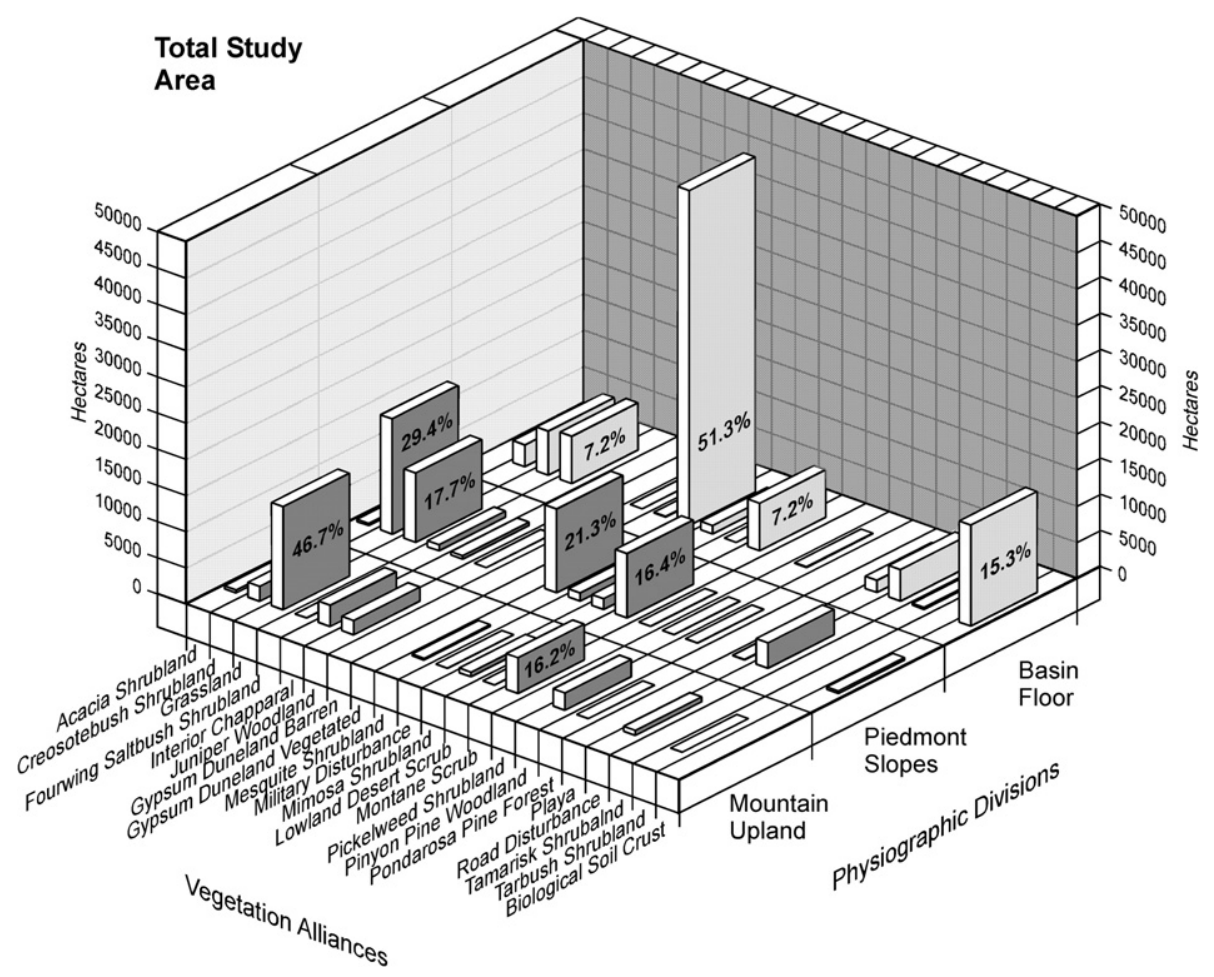

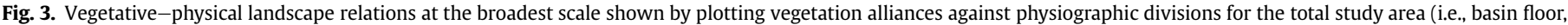

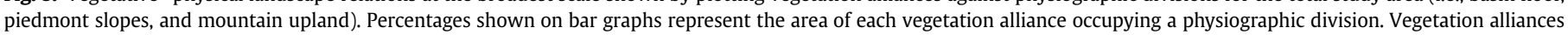
shown in bold are major vegetation types. 


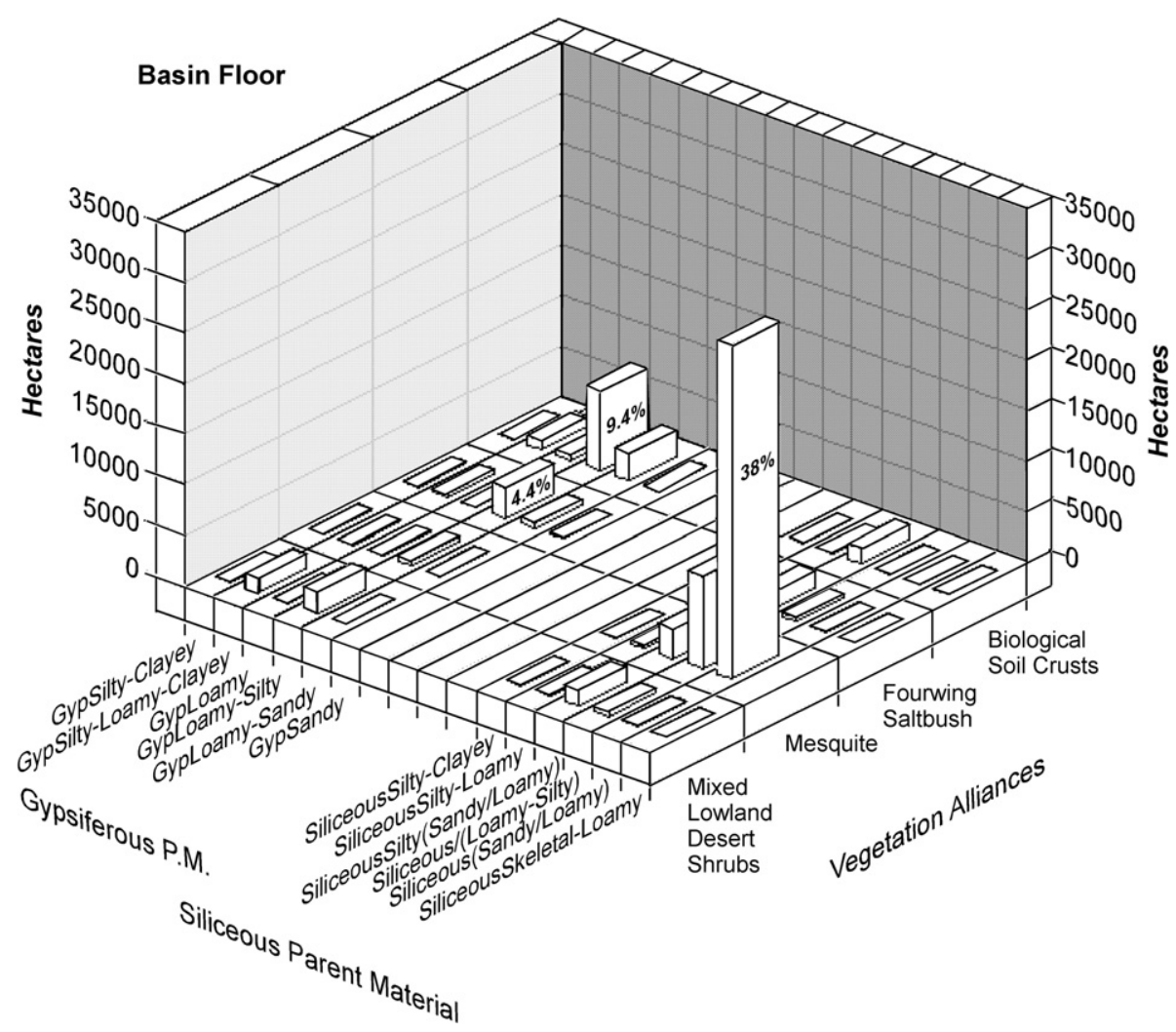

Fig. 4. Four most common vegetation alliances in the basin floor plotted against soil textures of gypsiferous versus siliceous parent material.

crust occurs mainly on the inactive gypsum dunes. The fourwing saltbush is not restricted to gypsiferous soils but is sparsely distributed across the two parent materials on a variety of alluvial and eolian landforms.

\subsection{Piedmont slopes}

Unlike the basin floor, piedmont slopes rise in elevation from $1184 \mathrm{~m}(3885 \mathrm{ft})$ to $1847 \mathrm{~m}(6060 \mathrm{ft})$. About $17 \%$ of its area is above the $1530 \mathrm{~m}(5000 \mathrm{ft})$ elevation contour, which is the approximate arid/semiarid boundary in the region (Gile et al., 1981) (Fig. 2). The lower-elevation arid zone receives $222-245 \mathrm{~mm}$ of annual precipitation (Malm, 1994; Wainwright, 2006) in contrast to the higher semiarid zone that receives $350-400 \mathrm{~mm}$ (NRCS, 1999). The piedmont slope contains 61 listed plant species in 7 vegetation alliances (Appendix 1). Taking the piedmont slope area as one unit, the dominant vegetation alliance is creosotebush shrubland (29.4\%) (Fig. 4). This is followed by mesquite shrubland (21.3\%), grasslands (17.7\%), and mixed lowland desert scrub (16.4\%).

Soil texture, especially gravel content, has long been recognized as an important factor for vegetation patterns on piedmont slopes (Gardner, 1951). In the arid zone of the piedmont slope, the dominant vegetation alliance is creosotebush shrubland on skeletal soils, which comprise $16.4 \%$ (8985 ha) of the total 54,668-ha piedmont slope division (Fig. 5). Grasslands in the arid zone are also most abundant on skeletal soils (8.6\%), while mesquite shrublands, like their distribution on the basin floor, are most abundant on sandy soils as coppice dunes over loamy soils (11.8\%). Mixed lowland desert scrub, which includes a mixture of creosotebush, mesquite, fourwing saltbush, and tarbush, is roughly the same on skeletal soils (5.8\%) as sandy/silty soils (6.6\%) (Fig. 5).

In the semiarid zone of the piedmont slope, grasslands are the dominant alliance of the 9219 ha unit and they become still more pronounced at higher elevations in the mountain upland unit. Grasslands on loamy soils (1.6\%) occupy a slightly greater area than grasslands on skeletal soils (1.1\%) (Fig. 5). Creosotebush on skeletal soils occupies $1.3 \%$, but other shrubs are negligible.

\subsection{Mountain upland}

Topographic relief in the mountain upland unit is its dominant characteristic, ranging in elevation from $1593 \mathrm{~m}$ (5226 ft) to $2522 \mathrm{~m}$ $(8024 \mathrm{ft})$, which is huge compared to the basin floor. This physiographic division contains 81 plant species in 15 vegetation alliances. The mountain upland category, being above $1530 \mathrm{~m}$ in elevation, is in the semiarid zone. For this unit as a whole, the dominant vegetation alliance is grassland (46.7\%) followed by montane scrub (16.2\%) (Fig. 3).

The mountain upland unit was subdivided into bedrock types to examine their importance to vegetation patterns (Alexander et al. 1985; Whittaker and Niering, 1968). Soils formed from different bedrock parent materials tend to have soils with different soil textures, water availability, and solution chemistry (Rose et al., 2003). Monzonite in the study area, for example, weathers to loamy, non-skeletal soils with high contents of kaolinitic clay (Gile et al., 1981). Rhyolite, on the other hand, is not easily comminuted into finer particles, but instead gives rise to skeletal soils with abundant amounts of dense, hard, slightly weathered rhyolite clasts.

The bedrock types were grouped into (1) igneous, which are dominantly silicic plutonic rocks and rhyolites; (2) metamorphic, chiefly granites and associated amphibolites and quartzites; and (3) sedimentary, primarily limestones and interbedded shale, sandstone, dolostone, and gypsum (Seager et al., 1987). The size of the bedrock areas vary greatly (e.g., $1 \%$ igneous, $14 \%$ metamorphic, and $54 \%$ sedimentary). The terrain in the mountain upland unit is very 


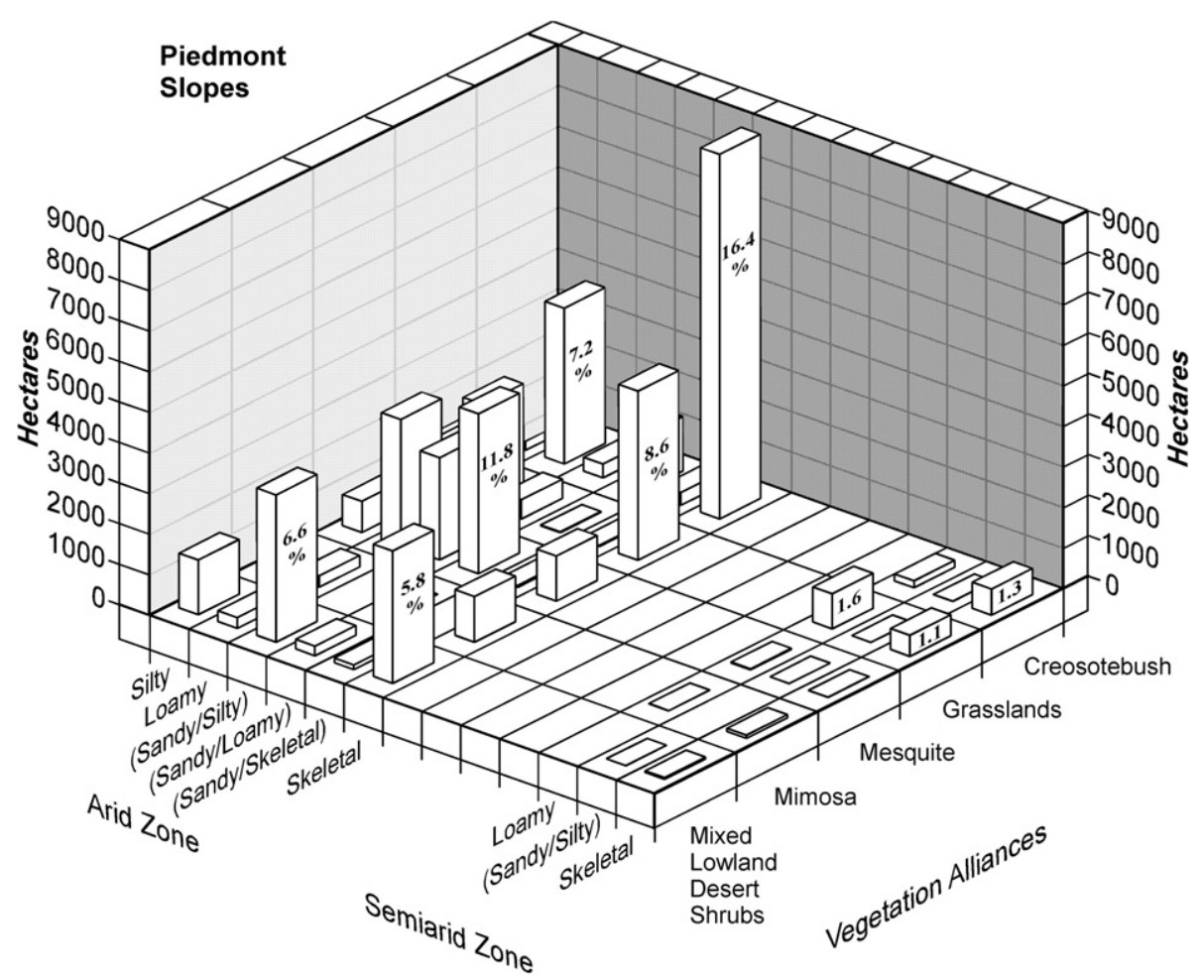

Fig. 5. Vegetation alliances plotted against various soil textures in the arid and semiarid zones of the piedmont slopes.

rugged, consisting of vertical cliffs, very steep boulder slopes, and rock-strewn gentler slopes of $15-60 \%$ that predominantly face the east and west. Colluvium and steep alluvial fan deposits are also common. Soils formed in limestone terrane have thin calcareous A and Bk horizons over bedrock at a depth of several centimeters. Soils formed in igneous and metamorphic terrane are also thin, but have less calcareous A and B horizons over bedrock, with welldeveloped Bt horizons on stable areas on gentler slopes (Gile and Grossman, 1979). Soils on all bedrock types have skeletal textures, except where eolian sand has accumulated in the intermountain valleys (Monger et al., 2006).

Relative amounts of the vegetation alliances for each bedrock type are shown in Fig. 6. The grassland alliance dominates all bedrock types, with the exception of igneous. The absence of grasslands on igneous rocks, however, appears to be an artifact of the small area (1\%) that the igneous rocks comprise in the study area. Elsewhere in the Organ and San Agustin Mountains grasslands are common on igneous bedrock (Gile and Grossman, 1979).

\section{Discussion of leading theories of mechanisms responsible for vegetation patterns}

\subsection{Mesquite coppice dunes on the basin floor}

Mesquite can occupy a variety of soil types and landforms and has the ability to be a facultative phreatophyte (Rundel and Nobel, 1991). It is the dominant species on deep sandy soils in basin floors in the study area and throughout southern New Mexico and northern Chihuahua, Mexico (Campbell, 1929; Dick-Peddie, 1993; Herbel et al., 1972; Langford, 2000). One explanation for mesquite's dominance is its rooting structures. These include a rapidly developing tap root that can descend to depths greater than $5.5 \mathrm{~m}$ in the study region, long lateral roots that extend at least $22 \mathrm{~m}$, and upward-turning roots that can access shallow soil water (Gibbens and Lenz, 2001; Gile et al., 1997). A second explanation is its ability to thrive in accumulating sand, which becomes mobilized following a reduction in grass cover and exposure of bare ground (Gibbens et al., 1983). Unlike black grama grass that cannot withstand burial by sand (Herbel et al., 1972), mesquite is well adapted to burial. As sand covers a mesquite plant, it sends out adventitious roots from buried stems and branches, and the plant grows upward with the accumulating sand. The sand and other wind-blown debris, including organic matter, contributes to a mesquite coppice dune being a preeminent resource island in which the dune itself becomes a zone of concentrated nutrients for the shrub (Schlesinger et al., 1990, 1996; Virginia and Jarrell, 1983; Wright, 1982; Wright and Honea, 1986).

Another explanation for mesquite on sandy soils concerns the antecedent occurrence of black grama grassland in this habitat. Black grama attracted cattle that became a vector of mesquite seed dispersal (Campbell, 1929), which worked in combination with selective herbivory of grasses (Buffington and Herbel, 1965). Still another explanation is a shift to more winter precipitation that favors $C_{3}$ shrubs (Neilson, 1986). According to this explanation, the rapid exploitation of shallow soil moisture ceased when $\mathrm{C}_{4}$ grasses disappeared; a factor that had formerly suppressed mesquite seedling establishment (Burgess, 1995).

\subsection{Biological soil crust on gypsum soils}

Throughout the arid and semiarid world, biological soil crust can be found in open spaces between sparse vegetation (Belnap et al., 2001). Sparse vegetation, in turn, is characteristic of gypsum soils in deserts of the American Southwest (Campbell and Campbell, 1938; Meyer, 1986). One explanation for sparse vegetation on gypsum soils is the chemical uniqueness of gypsum, notably the high sulfate levels or associated soluble salts. However, soils high in gypsum are not necessarily salt-affected. Gypsum by itself does not significantly increase osmotic potential or ionic toxicity (Herrero et al., 2009). In fact, gypsum has long been used as a source of 


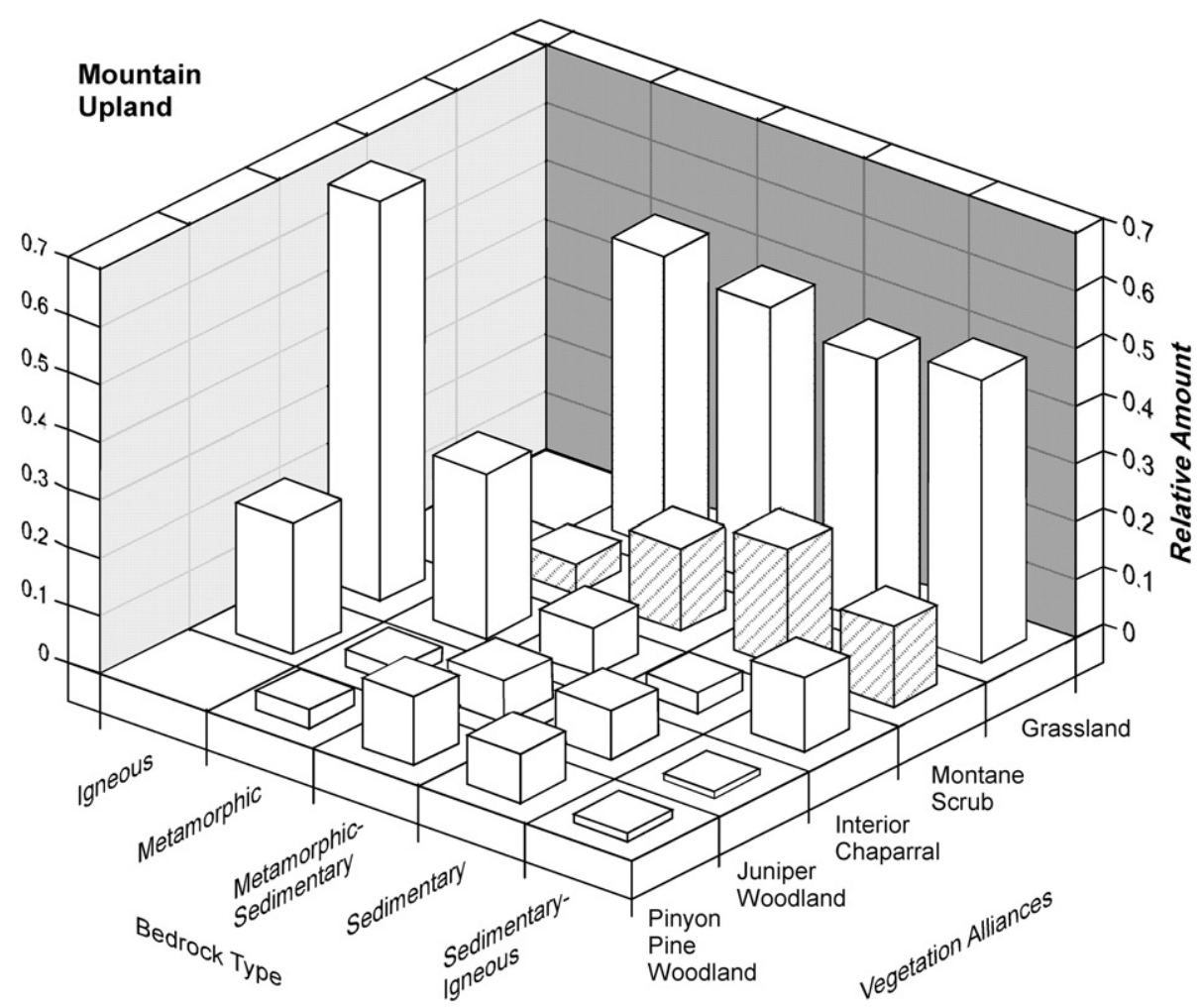

Fig. 6. Relative amounts of vegetation alliances in the mountains upland unit as a function of bedrock type.

calcium and sulfur for crops and a material to reclaim sodic soils. A comparison of chemical properties of gypsum soils with neighboring alluvial soils in the Mojave Desert revealed little chemical difference (Meyer, 1986). Her study found that it was not chemical properties, but physical properties that contributed to sparse vegetative cover, especially gypsic surface crusts that prevented plant establishment. A later study observed that dense gypsum horizons in the subsoil was a barrier to root penetration and thus contributed to vegetative sparseness (Gibbens and Lenz, 2001). Biological soil crusts, in contrast to vascular plants, have very low moisture requirements (Belnap et al., 2001). They also have high tolerance of extreme temperatures and light. Therefore, the dominance of biological soil crusts on the inactive gypsum dunes in the study area may be the result of the physical crust and petrogypsic horizons at or near the land surface that curtail plant establishment and provide unoccupied substrate for biological soil crust that can tolerate extreme conditions.

\subsection{Creosotebush on gravelly piedmont slopes}

Creosotebush occurs on numerous soils and landforms in the Southwest, although rarely in mobile sand, gypsum, or clayey soils with relatively low oxygen content (Buffington and Herbel, 1965; Gardner, 1951; Lunt et al., 1973). In southern New Mexico creosotebush primarily occurs on coarse-textured soils on bajada slopes - a habitat on which it has greatly expanded its area during the last 150 years (Gibbens et al., 2005; McCraw, 1985). One explanation is cresotebush's has high drought tolerance. Other factors held constant, gravelly bajadas are some of the driest soils on the landscape based on measurements of soil moisture from 1958 to 1976 (Herbel et al., 1994). The dryness of gravelly bajada soils can be attributed to their slope and rockiness. Slope gives rise to overland flow, especially when vegetation is sparse (Wainwright et al., 2000). As overland flow increases, the amount of moisture entering the soil profile decreases and reduces available soil water as compared to more gentle slopes (Gile et al., 1998). In addition, rock fragments occupy space in soil that could other hold water in fine pores (Hallmark and Allen, 1975). For example, the available water capacity of a clay loam with no rock fragments is $0.2 \mathrm{~cm} / \mathrm{cm}$ in contrast to $0.05 \mathrm{~cm} / \mathrm{cm}$ if the clay loam contains $75 \%$ rock fragments by volume (Table 5 in Herbel et al., 1994). The amount of water is further reduced if gravelly soils on bajada slopes have welldeveloped subsoil horizons that prevent deep water penetration (Hammerlynck et al., 2002).

\subsection{Grasslands in the mountain uplands}

Grasslands in the Chihuahuan Desert have been referred to as both "Semidesert Grasslands" (Brown, 1994) and "Desert Grasslands" (Dick-Peddie, 1993; McClaran, 1995). The reason grasslands dominate in the mountain upland unit of the study area is probably due to climate - that is, the mountain uplands reside in the suitable temperature and semiarid rainfall zone for Southwestern desert grasslands (Brown, 1994). In both the Chihuahuan and Sonoran Deserts, desert grasslands range in elevation from $1100 \mathrm{~m}$ in the northern regions to as high as $2500 \mathrm{~m}$ farther south in Mexico (McClaran, 1995) and have annual precipitation from 230 to $460 \mathrm{~mm}$ with annual temperatures ranging from 13 to $16{ }^{\circ} \mathrm{C}$. Precipitation in the mountain upland study area is roughly 350 $400 \mathrm{~mm}$ (NRCS, 1999). Temperatures are about $13{ }^{\circ} \mathrm{C}$ in the lower elevation dropping to $6{ }^{\circ} \mathrm{C}$ on the mountain peaks, based on a temperature decrease rate of $7.5^{\circ} \mathrm{C}$ per $1000 \mathrm{~m}$ in elevation (DickPeddie and Moir, 1970). Another factor may be fire, which is common in the mountain uplands of the study area. Grasslands in the Chihuahuan Desert, like grasslands in general, recover much faster than shrubs after being burned (McPherson, 1995). Fire is also more common in the mountain uplands because steep topography promotes its movement upslope. 


\section{Conclusions}

Many factors affect vegetation patterns in arid and semiarid regions. A geopedological framework can be used to broaden ecological studies beyond soil series by explicitly incorporating geologic and physiographic information. Using this technique, we examined a few of the many interacting geopedological variables and found that mesquite has a propensity for siliceous sand and aversion for gypsic soils, that biological soil crust is prone to occupy physically crusted gypseous soil, that drought tolerant creosotebush dominates rocky piedmont slopes, that grasslands dominate the semiarid piedmont slopes and mountain uplands regardless of bedrock type. We also note form these data that the number of plant species is greater in the high-relief mountain upland (36 plant species) and progressively less in the topographically simpler piedmont slope (27 plant species) and basin floor (26 plant species) units.

The geopedological approach can help researchers organize knowledge about intrinsic chemical and physical properties and extrinsic factors that influence vegetation patterns at multiple scales. This approach can be used in any region to supplement studies of vegetative-edaphic relationships based on maps of soil series. It is only necessary to obtain information from GIS overlays of topography (Digital Elevation Models), geology, soils, and vegetation maps, combined with aerial interpretations of landforms. Topographic maps allow the construction of the physiographic divisions, the geologic maps allow the construction of the regolith types and parent material, and the soil maps provide information about soil texture. Only the landforms must be constructed independently. However, they can be made using aerial images following procedures described in Peterson (1981) or Schoeneberger et al. (2002).

\section{Acknowledgments}

This research was supported in part by an appointment to the Student Environmental Management Participation Program at the U.S. Army Environmental Center administered by the Oak Ridge Institute for Science and Education through an interagency agreement between the U.S. Department of Energy and the U.S. Army Environmental Center. Additional support was provided by the Jornada Basin LTER program (DEB-94111971) and the New Mexico State University Agricultural Experiment Station. Comments by April Ulery, Jeff Herrick, Brandon Bestelmeyer, David Rachal, and Gretchen Michaud are greatly appreciated.

\section{Appendix 1. Supplementary material}

Supplementary material related to this article can be found at http://dx.doi.org/10.1016/j.jaridenv.2012.10.001.

\section{References}

Abrahams, A.D., Parsons, A.J., Wainwright, J., 1995. Effects of vegetation change on interrill runoff and erosion, Walnut Gulch, southern Arizona. Geomorphology $13,37-48$

Alexander, E.B., Wildman, W.E., Lynn, W.C., 1985. Ultramafic (serpentinitic) mineralogy class. In: Kittrick, J.A. (Ed.), Mineral Classification of Soils. Soil Science Society of America Special Publication Number 16, Madison, Wisconsin, pp. 135-146.

Alexander, E.B., Adamson, C., Graham, R.C., Zinke, P.J., 1989. Soils and conifer forest productivity on serpentinized peridotite of the Trinity Ophiolite, California. Soil Science $148,412-423$.

Allen, B.D., Love, D.W., Myers, R.G., 2009. Evidence for late Pleistocene hydrologic and climatic change from Lake Otero, Tularosa Basin, south-central New Mexico. New Mexico Geology 31, 9-25.

Bates, R.L., Jackson, J.A., 1987. Glossary of Geology. American Geological Institute, Alexandria, Virginia.

Beck, R.F., Gibbens, R.P., 1999. The Chihuahuan Desert ecosystem. New Mexico Journal of Science 39, 45-85.
Belnap, J., Kaltenecker, J.H., Rosentreter, R., Williams, J., Leonard, S., Eldridge, D., 2001. Biological Soil Crusts: Ecology and Management. Technical Reference 1730-2. US Dep Interior, Printed Materials Distribution Center, Denver, Colorado.

Bestelmeyer, B.T., Ward, J.P., Havstad, K.M., 2006a. Soil-geomorphic heterogeneity governs patchy vegetation dynamics at an arid ecotone. Ecology 87, 963-973.

Bestelmeyer, B.T., Trujillo, D.A., Tugel, A.J., Havstad, K.M., 2006b. A multi-scale classification of vegetation dynamics in arid lands: what is the right scale for models, monitoring, and restoration? Journal of Arid Environments 65, 296-318.

Box, T.W., 1961. Relationships between plants and soils of four range plant communities in south Texas. Ecology 42, 794-810.

Breshears, D.D., Barnes, F.J., 1999. Interrelationships between plant functional types and soil moisture heterogeneity for semiarid landscapes within the grassland/ forest continuum: a unified conceptual model. Landscape Ecology 14, 465-478.

Brown, D.E. (Ed.), 1994. Biotic Communities: Southwestern United States and Northwestern Mexico. University of Utah Press, Salt Lake City.

Browning, D.M., Archer, S.R., Asne, R.G.P., McClaran, M.P., Wessman, C.A., 2008. Woody plants in grasslands: post-encroachment stand dynamics. Ecological Applications 18, 928-944.

Buffington, L.C., Herbel, C.H., 1965. Vegetation changes on a semidesert grassland range. Ecological Monographs 35, 139-164.

Burgess, T.L., 1995. Desert grasslands, mixed shrub savanna, shrub steppe, or semidesert scrub? In: McClaran, M.P., Van Devender, T.R. (Eds.), The Desert Grasslands. Univ. Arizona Press, Tucson, pp. 31-67.

Cammeraat, L.H., 2002. A review of two strongly contrasting geomorphological systems within the context of scale. Earth Surface Processes and Landforms 27, 1201-1222.

Campbell, R.S., 1929. Vegetation succession in the Prosopis sand dunes of southern New Mexico. Ecology 10, 392-398.

Campbell, R.S., Campbell, I.F., 1938. Vegetation on gypsum soil of the Jornada Plain, New Mexico. Ecology 19, 572-577.

Coulombe, C.E., Wilding, L.P., Dixon, J.B., 2000. Vertisols. In: Sumner, M. (Ed.), Handbook of Soil Science. CRC Press, Boca Raton, pp. E269-E286.

Dick-Peddie, W.A., 1993. New Mexico Vegetation: Past, Present, and Future. University of New Mexico Press, Albuquerque.

Dick-Peddie, W.A., Moir, W.H., 1970. Vegetation of the Organ Mountains of Southern New Mexico. In: Range Science Department Science Series, vol. 4. Colorado State University, Fort Collins, CO.

Dregne, H.E., 1976. Soils of Arid Regions. Elsevier, Amsterdam.

Dregne, H.E., 1991. Human activities and soil degradation. In: Skujins, J. (Ed.), Semiarid Lands and Deserts. Marcel Dekker, Inc, New York, pp. 335-360.

Duniway, M.C., Herrick, J.E., Monger, H.C., 2007. The high water-holding capacity of petrocalcic horizons. Soil Science Society of America Journal 71, 812-819.

Fenneman, N.M., 1931. Physiography of the Western United States. McGraw-Hill Book Co, New York.

Gardner, J.L., 1951. Vegetation of the creostoebush area of the Rio Grande Valley in New Mexico. Ecological Monographs 21, 379-403.

Gibbens, R., Tromble, J., Hennessy, J., Cardenas, J., 1983. Soil movement in mesquite dunelands and former grasslands of southern New Mexico from 1933 to 1980 Journal of Range Management 36, 145-148.

Gibbens, R.P., Lenz, J.M., 2001. Root systems of some Chihuahuan Desert plants. Journal of Arid Environments 49, 221-263.

Gibbens, R.P., McNeely, R.P., Havstad, K.M., Beck, R.F., Nolen, B., 2005. Vegetation changes in the Jornada Basin from 1858 to 1998. Journal of Arid Environments $61,651-668$.

Gile, L.H., Hawley, J.W., 1966. Periodic sedimentation and soil formation on an alluvial-piedmont in southern New Mexico. Soil Science Society America Proceedings 30, 261-268.

Gile, L.H., Grossman, R.B., 1979. The Desert Project Soil Monograph. PB80-135304. National Technical Information Service, Springfield, WA.

Gile, L.H., Hawley, J.W., Grossman, R.B., 1981. Soils and Geomorphology in the Basin and Range Area of Southern New Mexico-guidebook to the Desert Project. Memoir, vol. 39. New Mexico Bureau of Mines and Mineral Resources, Socorro, New Mexico.

Gile, L.H., Gibbens, R.P., Lenz, J.M., 1997. The near-ubiquitous pedogenic world of mesquite roots in an arid basin floor. Journal of Arid Environments 35, 39-58.

Gile, L.H., Gibbens, R.P., Lenz, J.M., 1998. Soil-induced variability in root systems of creosotebush (Larrea tridentata) and tarbush (Flourensia cernua). Journal of Arid Environments 39, 57-78.

Grossman, D.H. Faber-Langensoen, D. Weakley, A.S, et al, 1998. International Classification of Ecological Communities: Terrestrial Vegetation of the United States. In: The National Vegetation Classification System: Development, Status, and Applications, vol. 1. The Nature Conservancy, Arlington, Virginia.

Hallmark, C.T., Allen, B.L., 1975. The distribution of creosotebush in west Texas and eastern New Mexico as affected by selected soil properties. Soil Science Society of America Proceedings 39, 120-124.

Hammerlynck, E.P., McAuliffe, J.R., McDonald, E.V., Smith, S.D., 2002. Ecological responses of two Mojave Desert shrubs to soil horizon development and soil water dynamics. Ecology 83, 768-779.

Hawley, J.W., 1975. Quaternary history of Doña Ana County region, south-central, New Mexico. In: Seager, W., Clemons, R., Callender, J.F. (Eds.), Field Conference Guidebook of the Las Cruces Country. New Mexico Geological Society, pp. 139-150.

Hawley, J.W., 1993. Geomorphic Setting and Late Quaternary History of Pluvial-lake Basins in the Southern New Mexico Region. Open-File Report 391. New Mexico Bureau of Mines and Mineral Resources, Soccorro, NM. 
Hawley, J.W., 2005. Five million years of landscape evolution in New Mexico: an overview based on two centuries of geomorphic conceptual-model development. In: Lucas, S.G., Morgan, G.S., Zeigler, K.E. (Eds.), New Mexico's Ice Ages. Museum of Natural History and Science Bulletin, vol. 28, pp. 9-93.

Herbel, C.H., Ares, F.N., Wright, R.A., 1972. Drought effects on a semidesert grassland range. Ecology 53, 1084-1093.

Herbel, C.H., Gile, L.H., Fredrickson, E.L., Gibbens, R.P., 1994. Soil Water and Soils at Soil Water Sites, Jornada Experimental Range. Soil Survey Investigations Report No 44. Natural Resources Conservation Service, Lincoln, Nebraska.

Herrick, J.E., Brown, J.R., Tugel, A.J., Shaver, P.L., Havstad, K.M., 2002. Application of soil quality to monitoring and management: paradigms from rangeland ecology. Agronomy Journal 94, 3-11.

Herrero, J., Porta, J., 2000. The terminology and the concepts of gypsum-rich soils. Geoderma 96, 47-61.

Herrero, J., Artieda, O., Hudnall, W.H., 2009. Gypsum, a tricky material. Soil Science Society of America Journal 73, 1757-1763.

Langford, R.P., 2000. Nabkha (Coppice dune) fields of south-central New Mexico, USA. Journal of Arid Environments 45, 25-41.

Langford, R.P., 2003. The Holocene history of the White Sands dune field and influences on eolian deflation and playa lakes. Quaternary International 104, 207-218.

Little Jr., E.L., Campbell, R.S., 1943. Flora of Jornada Experimental Range, New Mexico. American Midland Naturalist 30, 626-670.

Ludwig, J.A., Wilcox, B.P., Breshears, D.D., Tongway, D.J., Imeson, A.C., 2005. Vegetation patches and runoff-erosion as interacting ecohydrological processes in semiarid landscapes. Ecology 86, 288-297.

Lunt, O.R., Letey, J., Clark, S.B., 1973. Oxygen requirements for root growth in three species of desert shrubs. Ecology 54, 1356-1362.

McAuliffe, J.R., 1994. Landscape evolution, soil formation, and ecological patterns and processes in Sonoran Desert bajadas. Ecological Monographs 64, 111-148.

McClaran, M.P., 1995. Desert grasslands and grasses. In: McClaran, M.P., Van Devender, T.R. (Eds.), The Desert Grasslands. Univ. Arizona Press, Tucson, pp.1-30.

McCraw, D.J. 1985. Phytogeographic History of Larrea in Southwestern New Mexico Illustrating the Historical Expansion of the Chihuahuan Desert. Dissertation, University of New Mexico, Albuquerque.

McFadden, L.D., McAuliffe, J.R., 1997. Lithologically influenced geomorphic responses to Holocene climatic changes in the southern Colorado Plateau, Arizona: a soilgeomorphic and ecologic perspective. Geomorphology 19, 303-332.

McPherson, G., 1995. The role of fire in desert grasslands. In: McClaran, M.P., Van Devender, T.R. (Eds.), The Desert Grasslands. Univ. Arizona Press, Tucson, pp. 130-151.

Malm, N.R., 1994. Climatic Guide, Las Cruces, 1892-1991. Agricultural Experiment Station, Research Report 682. New Mexico State University, Las Cruces.

Meyer, S.E., 1986. The ecology of gypsophile endemism in the eastern Mojave Desert. Ecology 67, 1303-1313.

Michaud, G.M., 2000. The Relationship Between Vegetation and Geomorphology Using a Geopedologcial Classification System. MS thesis, New Mexico State University, Las Cruces.

Monger, H.C., Bestelmeyer, B.T., 2006. The soil-geomorphic template and biotic change in arid and semi-arid ecosystems. Journal of Arid Environments 65, 207-218.

Monger, H.C., Mack, G.H., Nolen, B.A., Gile, L.H., 2006. Regional setting of the Jornada LTER. In: Havstad, K., Huenneke, L.F., Schlesinger, W.H. (Eds.), Structure and Function of a Chihuahuan Desert Ecosystem: the Jornada Basin Long Term Ecological Research Site. Oxford Univ. Press, Oxford, pp. 15-43.

Monger, H.C., Cole, D.R., Buck, B.J., Gallegos, R.A., 2009. Scale and the isotopic record of $\mathrm{C}_{4}$ plants in pedogenic carbonate: from the biome to the rhizosphere. Ecology 90, 1498-1511.

Muldavin, E., Chauvin, Y.G., Harper, G., 2000a. The Vegetation of White Sands Missile Range, New Mexico. In: Handbook of Vegetation Communities, vol. I. University of New Mexico, Albuquerque.

Muldavin, E., Harper, G., Neville, P., Chauvin, Y., 2000b. The Vegetation of White Sands Missile Range, New Mexico. In: Vegetation Map, vol. II. University of New Mexico, Albuquerque.

Neher, R.E., Bailey, O.F., 1976. Soil Survey of White Sands Missile Range, New Mexico. US Department of Agriculture SCS. US Government Printing Office, Washington, DC

Neilson, R.P., 1986. High-resolution climatic analysis and southwest biogeography. Science 232, 27-34.

NRCS, 1999. New Mexico Annual Precipitation. USDA-NRCS National Cartography \& Geospatial Center, Fort Worth, Texas.

Parsons, A.J., Wainwright, J., Schlesinger, W.H., Abrahams, A.D., 2003. The role of overland flow in sediment and nitrogen budgets of mesquite dunefields, southern New Mexico. Journal of Arid Environments 53, 61-71.

Peters, D.P.C., Pielke, R.A., Bestelmeyer, B.T., Allen, C.D., Munson-McGee, S., Havstad, K.M., 2004. Cross-scale interactions, nonlinearities, and forecasting catastrophic events. Proceedings of the National Academy of Science 101, 15130-15135

Peters, D.P.C., Bestelmeyer, B.T., Herrick, J.E., Monger, H.C., Fredrickson., E., Havstad, K.M., 2006. Disentangling complex landscapes: new insights into arid and semiarid system dynamics. BioScience 56, 491-501.

Peterson, F.F., 1981. Landforms of the Basin and Range Province Defined for Soil Survey. Nevada Agricultural Experiment Station, Technical Bulletin No. 28 Reno, Nevada.

Pickup, G., 1985. The erosion cell-a geomorphic approach to landscape classification in range assessment. Australian Rangeland Journal 7, 114-121.
Puigdefabregas, J., Sola, A., Gutierrez, L., del Barrio, G., Boer, M., 1999. Scales and processes of water and sediment redistribution in drylands: results from the Rambla Honda field in southeast Spain. Earth-Science Reviews 48, 39-70.

Rachal, D.M., Monger, H.C., Okin, G.S., Peters, D.P.C., 2012. Landform influences on the resistance of grasslands to shrub encroachment, Northern Chihuahuan Desert, USA. Journal of Maps. http://dx.doi.org/10.1080/17445647.2012.727593.

Rango, A., Tartowski, S.L., Laliberte, A., Wainwright, J., Parsons, A., 2006. Islands of hydrologically enhanced biotic productivity in natural and managed arid ecosystems. Journal of Arid Environments 65, 235-252.

Rose, K.L., Graham, R.C., Parker, D.R., 2003. Water source utilization by Pinus jeffrey and Arctostaphylos patula on thin soils over bedrock. Oecologia 134, 46-54.

Rundel, P.W., Nobel, P.S., 1991. Structure and function in desert root systems. In: Atkinson, D. (Ed.), Plant Root Growth: an Ecological Perspective. Blackwell Scientific Publications, London, UK, pp. 349-378.

Satterwhite, M.B., Ehlen, J., 1982. Landform-vegetation relationships in the northern Chihuahuan Desert. In: Yaalon, D.H. (Ed.), Aridic Soils and Geomorphic Processes. Catena Supplement 1, Braunschweig, pp. 195-209.

Schlesinger, W.H., Reynolds, J.F., Cunningham, G.L., Huenneke, L.F., Jarrell, W.M., Virginia, R.A., Whitford, W.G., 1990. Biological feedbacks in global desertification. Science 247, 1043-1048.

Schlesinger, W.H., Raikes, J.A., Hartley, A.E., Cross, A.F., 1996. On the spatial pattern of soil nutrients in desert ecosystems. Ecology 77, 364-374.

Schlesinger, W.H., Ward, T.J., Anderson, J., 2000. Nutrient losses in runoff from grassland and shrubland habitats in southern New Mexico: II. field plots. Biogeochemistry 49, 69-86.

Schmidt Jr., R.H., 1979. A climatic delineation of the "real" Chihuahuan Desert. Journal of Arid Environments 2, 243-250.

Seager, W.R., 1981. Geology of the Organ Mountains and Southern San Andres Mountains, New Mexico, Memoir 36. New Mexico Bureau of Mines and Minera Resources, Socorro, New Mexico.

Seager, W.R., Shafiquallah, M., Hawley, J.W., Marvin, R.F., 1984. New K-Ar dates from basalt and the evolution of the southern Rio Grande rift. Geological Society of American Bulletin 95, 87-99.

Seager, W.R., Hawley, J.W., Kottlowski, F.F., Kelly, S.A., 1987. Geology of the East Half of Las Cruces and Northeast El Paso $1^{\circ} \times 2^{\circ}$ Sheets, New Mexico. Geology Map 57. New Mexico Bureau of Mines and Mineral Resources, Socorro, New Mexico.

Schoeneberger, PJ., Wysocki, D.A, Benham, E.C., Broderson, W.D. (Eds.), 2002. Field 753 Book for Describing and Sampling Soils. Version 2.0. NRCS-NSSC, Lincoln, NE.

Soil Survey Staff, 1999. Soil Taxonomy-a Basic System of Soil Classification for Making and Interpreting Soil Surveys. U.S. Department of Agriculture, Natura Resources Conservation Service, Washington DC.

Virginia, R.A., Jarrell, W.M., 1983. Soil properties in a mesquite-dominated Sonoran Desert ecosystem. Soil Science Society of America Journal 47, 138-144.

Wainwright, J., Parsons, A.J., Abrahams, A.D., 2000. Plot-scale studies of vegetation, overland flow and erosion interactions: case studies from Arizona and New Mexico. Hydrological Processes 14, 2921-2943.

Wainwright, J., 2006. Climate and climatological variations in the Jornada Basin. In: Havstad, K., Huenneke, L.F., Schlesinger, W.H. (Eds.), Structure and Function of a Chihuahuan Desert Ecosystem: the Jornada Basin Long Term Ecological Research Site. Oxford Univ. Press, Oxford, pp. 44-80.

Walsh, S.J., Butler, D.R., Malanson, G.P., 1998. An overview of scale, pattern, process relationships in geomorphology: a remote sensing and GIS perspective. Geomorphology 21, 183-205.

Weems, S.L., Monger, H.C., March 2012. Banded vegetation-dune formation in the Medieval warm period and 20th century, Chihuahuan Desert, New Mexico, USA. Ecosphere 3 (3). Article 21. www.esajournals.org.

Wierenga, P.J., Hendricks, J.M.H., Nash, M.H., Ludwig, J., Daugherty, L.A., 1987 Variation of soil and vegetation with distance along a transect in the Chihuahuan Desert. Journal of Arid Environments 13, 53-63.

Whittaker, R.H., Niering, W.A., 1968. Vegetation of the Santa Catalina Mountains, Arizona: IV. Limestone and acid soils. Journal of Ecology 56, 523-544.

Wondzell, S., Ludwig, J.A., 1995. Community dynamics of desert grasslands: influences of climate, landforms, and soils. Journal of Vegetation Science 11, 377-390.

Wondzell, S.M., Cunningham, G.L., Bachelet, D., 1987. A hierarchical classification of landforms: some implications for understanding local and regional vegetation dynamics. Technical Report RM-150. In: Strategies for Classification and Management of Native Vegetation for Food Production in Arid Zones. Fort Collins, Colorado, pp. 15-23.

Wondzell, S.M., Cunnigham, G.L., Bachelet, D. 1996. Relationships between landforms, geomorphic processes and plant communities on a watershed in the northern Chihuahuan Desert. Landscape Ecology 11, 351-362.

Wright, R.A., 1982. Aspects of desertification in Prosopis dunelands of southern New Mexico, USA. Journal of Arid Environments 5, 277-284.

Wright, R.A., Honea, J.H., 1986. Aspects of desertification in southern New Mexico, U.S.A.: soil properties of a mesquite duneland and former grassland. Journal of Arid Environments 11, 139-145.

Yetemen, O., Istanbulluoglu, E., Vivoni, E.R., 2010. The implications of geology, soils and vegetation on landscape morphology: inferences from semiarid basins with complex vegetation patterns in central New Mexico, USA. Geomorphology 116 246-263.

Yao, J., Peters, D.P.C., Havstad, K.M., Gibbens, R.P., Herrick, J.E., 2006. Multi-scale factors and long-term responses of Chihuahuan Desert grasses to drought Landscape Ecology 21, 1217-1231.

Zonneveld, I.S., 1989. The land unit-a fundamental concept in landscape ecology, and its applications. Landscape Ecology 3, 67-86. 


\section{Supplementary Material}

\section{Appendix 1}

Plant species contained in vegetation alliances of the basin floor, piedmont slopes and mountain upland (from Muldavin et al. 2000a, 2000b). Common names are given in parenthesis.
Vegetation Alliance
Plant Species

5 BASIN FLOOR [26 species total]

Creosotebush Shrubland

Gypsum Duneland Barren

Gypsum Duneland Vegetated

Gypsum Interdune Swale

Grassland

Lowland Basin Grasslands

Mesquite Shrubland
Larrea tridentata (Creosotebush)

Prosopis glandulosa (Honey Mesquite)

Gutierrezia sarothrae (Snakeweed)

Flourensia cernua (Tarbush)

Fourwing Saltbush Shrubland

Atriplex canescens (Fourwing Saltbush)

Sporobolus airoides (Alkali sacaton)

Pleuraphis mutica (Tobosa)

Scleropogon brevifolius (Burrograss)

Allenrolfea occidentalis (Iodine Bush)

Suaeda suffrutescens (Desert Seepweed)

Psorothamus scoparius (Purple Sage)

Poliomintha incana (Hoary Rosemint)

Sporobolus flexuosus (Mesa Dropseed)

Sporobolus contractus (Spike Dropseed)

Sporobolus nealleyi (Gyp Dropseed)

Sporobolus airoides (Alkali Sacaton)

Yucca elata (Soaptree Yucca)

Ephedra torreyana (Torrey Joint Fir)

Atriplex canescens (Fourwing saltbush)

Sporobolus airoides (Alkali sacaton)

Sporobolus airoides (Alakali sacaton)

Scleropogon brevifolius (Burrograss)

Plueraphis mutica (Tobosa)

Prosopis glandulosa (Honey Mesquite) 
Gutierrezia sarothrae (Snakeweed)

Sporobolus flexuosus (Mesa Dropseed)

Atriplex canescens (Fourwing Saltbush)

Yucca elata (Soaptree Yucca)

Military Disturbance

No Plant Species; Disturbance caused by Military Testing and Development

Mixed Lowland Desert Scrub

Lycium berlandieri var. berlandieri (BlueFlowered Wolfberry)

Sporobolus nealleyi (Gyp Dropseed)

Scleropogon brevifolius (Burrograss)

Pickleweed Shrubland

Allenrolfea occidentalis (Iodine Bush)

Playa

Eleocharis palustris (Pale Spikerush)

Polypogon monspeliensis (Rabbitfoot

Grass)

Typha angustifolia (Narrowleaf Cattail)

Xanthium strumarium(Cocklebur

Distichlis spicata var stricta (Inland

Saltgrass)

Typha latifolia (Broadleaf Cattail)

Tamarisk Shrubland

Tamarix chinensis (Saltcedar)

Allenrolfea occidentalis (Iodine Bush)

Sporobolus airoides (Alakali sacaton)

Vegetated Gypsum Outcrop Cryptobiotic Crust

Sporobolus nealleyi (Gyp Dropseed)

Tiquilia hispidissima (Hairy Crinklemat)

Atriplex canescens (Fourwing Saltbush)

PIEDMONT SLOPES [27 species total]

Acacia Shrubland

Creosotebush Shrubland
Acacia constricta (Whitethorn Acacia)

Acacia neovernicosa (Viscid Acacia)

Larrea tridentata (Creosotebush)

Parthenium incanum (Mariola)

Prosopis glandulosa (Honey Mesquite) 
Lycium berlandieri (Blue-Flowered

Wolfberry)

Muhlenbergia porteri (Bush Muhly)

Atriplex canescens (Fourwing Saltbush)

Flourensia cernua (Tarbush)

Aristida purpurea (Threeawn)

Lowland Basin Grasslands

Prosopis glandulosa (Honey Mesquite)

Larrea tridentata (Creosotebush)

Atriplex canescens (Fourwing Saltbush)

Flourensia cernua (Tarbush)

Miltiary Disturbance

No Plant Species; Disturbance caused by

Military Testing and Development

Mimosa Shrubland

Mimosa acueleaticarpa var biuncifera

(Wait-A-Minute-Bush)

Tridens muticus var muticus (Slim

Tridens)

Bouteloua eriopoda (Black Grama)

Bouteloua curtipendula (Side-Oats

Grama)

Viguiera stenoloba (Slimleaf Goldeneye)

Pallaea intermedia Intermediate

Cliffbreak

Muhlenbergia porteri (Bush Muhly)

Ericameria laricifolia (Turpentine Bush)

Mixed Foothill-Piedmont Desert

Grasslands

Bouteloua curtipendula (Side-Oats

Grama)

Tridens muticus var muticus (Slim

Tridens)

Bouteloua eriopoda (Black Grama)

Aristida purpurea var perplexa

(Perplexing Purple Three-Awn)

Viguiera stenoloba (Slimleaf Goldeneye)

Mimosa acueleaticarpa var biuncifera

(Wait-A-Minute-Bush)

Dalea formosa (Feather Indigobush)

Parthenium incanum (Mariola)

Nolina texana (Texas Beargrass)

Mixed Lowland Desert Scrub Sporobolus airoides (Alkali sacaton)

Gutierrezia sarothrae (Snakeweed) 
Aristida purpurea var perplexa

(Perplexing Purple Three-Awn)

Prosopis glandulosa (Honey Mesquite)

Mimosa acueleaticarpa var biuncifera

(Wait-A-Minute-Bush)

Muhlenbergia porteri (Bush Muhly)

Flourensia cernua (Tarbush)

Larrea tridentata (Creosotebush)

Parthenium incanum (Mariola)

Dasyochloa pulchella (Fluffgrass)

Yucca elata (Soaptree Yucca)

Piedmont Desert Grasslands Bouteloua eriopoda (Black Grama)

Bouteloua curtipendula (Side-Oats

Grama)

Aristida purpurea var fendleriana

(Fendler's Threeawn)

Dasyochloa pulchella (Fluffgrass)

MOUNTAIN UPLANDS [36 species total]

Acacia Shrubland

Interior Chaparral

Grassland
Acacia constricta (Whitethorn Acacia)

Acacia neovernicosa (Viscid Acacia)

Foothill-Montane Temperate

Bouteloua eriopoda (Black grama)

Bouteloua hirsuta (Hairy grama)

Stipa sp.(Needlegrass)

Quercus turbinella var. turbinella

Desert Scrub Oak

Agave neomexicana (New Mexico

agave)

Dasylirion wheeleri (Sotol)

Bouteloua curtipendula (Side-Oats

grama)

Bouteloua eriopoda (Black grama)

Parthenium incanum (Mariola)

Yucca baccata (Banana Yucca)

Stipa neomexicana (New Mexico

Feathergrass)

Nolina texana (Texas Beargrass) 
Juniper Woodland

Mixed Foothill-Piedmont Desert Grasslands

Montane Scrub
Dalea formosa (Feather Indigobush) Viguiera stenoloba (Slimleaf Goldeneye)

Juniperus monosperma (One Seed Juniper) Juniperus deppeana (Alligator bark Juniper)

Juniperus coahuilensis var arizonica (Roseberry Juniper) Muhlenbergia pauciflora (New Mexico Muhly) Muhlenbergia setifolia (Curlyleaf Muhly)

Stipa sp. (Needlegrass)

Bouteloua sp. (Grama Grass)

Stipa neomexicana (New Mexico Feathergrass)

Bouteloua curtipendula (Side-Oats grama)

Tridens muticus var muticus (Slim Tridens)

Bouteloua eriopoda (Black grama) Aristida purpurea var perplexa (Perplexing Purple Three-Awn) Viguiera stenoloba (Slimleaf Goldeneye)

Mimosa acueleaticarpa var biuncifera (Wait-A-Minute-Bush)

Dalea formosa (Feather Indigobush)

Parthenium incanum (Mariola)

Cercocarpus breviflorus var. breviflorus (Mountain mahogany Quercus turbinella var. turbinella Desert Scrub Oak

Rhamnus serrata var. serrata (Sawleaf Buckthorn)

Agave neomexicana (New Mexico agave)

Dasylirion wheeleri (Sotol)

Bouteloua curtipendula (Side-Oats

Grama)

Bouteloua eriopoda (Black Grama) 
Parthenium incanum (Mariola)

Yucca baccata (Banana Yucca)

Piedmont Desert Grasslands Bouteloua eriopoda (Black Grama)

Bouteloua curtipendula (Side-Oats

Grama)

Aristida purpurea (Threeawn)

Dasyochloa pulchella (Fluffgrass)

Piedmont Temperate

Grasslands

Bouteloua gracilis (Blue Grama)

Bouteloua curtipendula var

curtipendula (Side-Oats grama)

Pinyon Pine Woodland Pinus edulis (Pinyon Pine)

Nolina texana (Texas Beargrass)

Muhlenbergia pauciflora (New

Mexico muhly)

Cercocarpus breviflorus var.

breviflorus (Mountain mahogany

Rhus trilobata var trilobata

(Skunkbush Sumac)

Tarbush Shrubland

Flourensia cernua (Tarbush)

Sporobolus airoides (Alkali sacaton)

Larrea tridentata (Creosotebush) 